\title{
Detecting hypertension: screening versus case finding in Norway
}

\author{
Jostein Holmen, Lisa Forsén, Peter F Hjort, Kristian Midthjell, Hans Th Waaler, Arild Bjørndal
}

National Institute of Public Health, Community Medicine Research Centre, Verdal, PO Box 234, N-7651 Verdal, Norway Jostein Holmen, MD, research fellow Kristian Midthjell, MD, research fellow

National Institute of Public Health, Unit for Health Services Research, Oslo Lisa Forsén, CAND REAL, fellow in statistics

Peter F Hjort, PHD, professor of medicine

Hans Th Waaler, PHD, professor of health services research

Arild Bjørndal, MD, research fellow

Correspondence and requests for reprints to: Dr Holmen.

\begin{abstract}
Objective-Evaluation of detection of hypertension in adults in the county of Nord-Trøndelag, Norway.

Design-Cross sectional survey with clinical follow up examinations.

Setting-Health survey by screening teams from the national health screening service, and examinations by all 106 general practitioners in the county.

Subjects-During 1984-6, 74977 persons (88.1\% of those aged 20 years and over) participated in the health survey.
\end{abstract}

Main outcome measures-Hypertension (when assessed by standardised recording and by questionnaires on drug treatment for hypertension) according to the blood pressure thresholds used in the Norwegian treatment programme. Subjects positive on screening were grouped after clinical examination into treatment groups.

Results - In all, 2399 subjects were positive for hypertension. Before screening $6210(8 \cdot 3 \%)$ patients reported taking antihypertensive drugs and another $3849(5 \cdot 1 \%)$ had their blood pressure monitored regularly. All who screened positive were referred to their general practitioner and evaluated according to a standard programme. As a result, drug treatment was started in $406(0.5 \%)$ participants screened and blood pressure monitoring in another 1007 (1.3\%). Of all patients taking antihypertensive drugs after the screening, $6399(94.0 \%)$ had been diagnosed before screening, and of those whose blood pressure was monitored after the screening, $79.3 \%$ had been diagnosed before screening.

Conclusions-At the blood pressure screening thresholds used, and when hypertension is defined by an overall clinical diagnosis, the results indicate that general practitioners can find and diagnose hypertensive patients with the case finding strategy.

\section{Introduction}

During the 1970s several studies showed poor treatment of hypertensive patients, and the rule of halves was introduced ${ }^{12}$; it suggested that only one half of the people with hypertension in a population were diagnosed. Several studies confirmed this rule. ${ }^{3-5}$ To improve the quality of care of hypertensive patients, including diagnostic procedures, actions were taken in several countries. Treatment programmes were developed $^{6-10}$; some countries established hypertension clinics $^{11-14}$; and many claimed that hypertensive patients should be taken care of by specialists or by hypertension clinics and not by general practitioners. ${ }^{11} 121516$ In the United States treatment has improved considerably through the past decade, ${ }^{17}$ but in other countries the rule of halves still applies. ${ }^{18}$

Most hypertensive patients in Norway are treated by general practitioners, and in the 1970s the treatment situation was as poor as in other countries, especially for patients under 50 years of age. ${ }^{19}$ Our research programme aims at studying and improving the care of the hypertensive patients served by the primary health care system rather than by special clinics and specialised health staff.

A treatment programme for hypertension in general practice was developed..$^{21}$ It was based on a 10 year follow up study of a large Norwegian population..$^{22}$ In the county of Nord-Trøndelag (125000 inhabitants) in central Norway a research programme was introduced in 1980 to evaluate treatment of hypertension. In age and sex distribution the population is comparable to Norway as a whole. The mortality and living conditions are similar to those of the 18 other counties in Norway, although Nord-Trøndelag has no cities with over 50000 residents and the mean income is lower than the national average. The medical system in the county included two hospitals and 60 general practitioners in 1980. By 1986 the number of general practitioners had increased to 100 .

From earlier studies we expected that many people with hypertension had not been diagnosed. Therefore this study asked: In how many patients had hypertension not been diagnosed by general practitioners? Were general practitioners capable of detecting hypertension or should action be taken to organise mass screenings and to establish hypertension clinics throughout Norway.

\section{Patients and methods} PILOT STUDIES

In 1980 the general practitioners in the county registered all the patients taking antihypertensive drugs who they saw during an eight week period. A sample of the patients and all the general practitioners were then interviewed. ${ }^{23}$ In 1981 a treatment programme was developed and distributed to all general practitioners and to the local hospitals. The general practitioners were advised to use the case finding method to detect hypertension in their patients by measuring blood pressure whenever symptoms suggested hypertension and in all routine health examinations. In 1980, 1981, and 1984 courses were held for doctors and nurses, including practical training in the technique of measuring blood pressure. During 1980-4 general practitioners also received written information about the treatment programme and preliminary results that suggested that a large proportion of hypertensive men and young people had not been identified. For a 12 month period in 1982-3 general practitioners were therefore asked to measure blood pressure in all patients visiting them.

\section{SCREENING}

From January 1984 to February 1986 all residents of Nord-Trøndelag county aged 20 years or older were invited to a health screening. Each person received a letter with an information folder, the time of the 
examination, and a questionnaire. Out of 85100 people invited, $74977(88 \cdot 1 \%)$ participated. Participation was highest among middle aged subjects and women and lower among those who were unmarried, divorced, or separated and among those living in the largest municipalities. Comparison of non-participants with participants showed no difference in prevalence of hypertension before screening. ${ }^{24}$

Height, weight, blood pressure, pulse, and results of chest $x$ ray examination were recorded in all participants. The participants answered a questionnaire before the screening and were asked to return a second questionnaire by mail.

The screening was performed by specially trained nurses. Blood pressure was measured in the right arm after the patient had been sitting for two minutes. Calibrated mercury manometers with standard cuff size $(12 \times 24 \mathrm{~cm})$ were used. The mercury level at first pulse sound (phase I) was registered as the systolic blood pressure and the level at which the pulse sound disappeared (phase V) was registered as the diastolic blood pressure. Both systolic and diastolic blood pressures were registered with an accuracy of $2 \mathrm{~mm} \mathrm{Hg}$ and repeated two minutes later. Both readings were recorded. The procedure is described in detail elsewhere..$^{25}$

\section{CRITERIA FOR HYPERTENSION}

The Norwegian treatment programme ${ }^{2021}$ is based on a definition of hypertension according to age and sex (figure). Patients with systolic or diastolic blood pressure above screening thresholds were defined as having screened positive for hypertension and were referred to their general practitioners, who used the thresholds in the diagram to determine the need to start drug treatment. Patients with systolic or diastolic blood pressure above the threshold lines after repeated measurements received drug treatment. Patients with systolic blood pressure 1-10 $\mathrm{mm} \mathrm{Hg}$ under the systolic threshold or 1-5 $\mathrm{mm} \mathrm{Hg}$ under the diastolic threshold had their blood pressure regularly monitored but were not given drug treatment.

\section{EXAMINATIONS AFTER SCREENING}

All subjects who screened positive for hypertension were referred to their general practitioners for further examinations. General practitioners were advised to use the blood pressure measurement technique described above, modified slightly, to measure both systolic and diastolic blood pressure three times with at least one minute between readings and to use the mean of the two measurements for systolic and diastolic blood pressure as the patient's blood pressure. General practitioners were instructed to measure blood pressure on at least two occasions before making a definitive diagnosis.

According to the programme, the general practitioners should also consider other cardiovascular risk factors such as family history of cardiovascular disease, cigarette smoking, raised cholesterol concentrations, overweight, diabetes, and previous cardiovascular diseases. Quality of life and the patients' own views on blood pressure monitoring and drug treatment should also be considered. Thus, the blood pressure should not be used alone to decide whether further blood pressure monitoring or drug treatment should be initiated.

Based on an overall clinical judgment, the general practitioners were asked to place each patient into one of four groups: group 1: no treatment or monitoring necessary; group 2: no treatment necessary, but blood pressure should be monitored; group 3: already being treated with antihypertensive drugs; group 4: newly discovered hypertension, needing antihypertensive

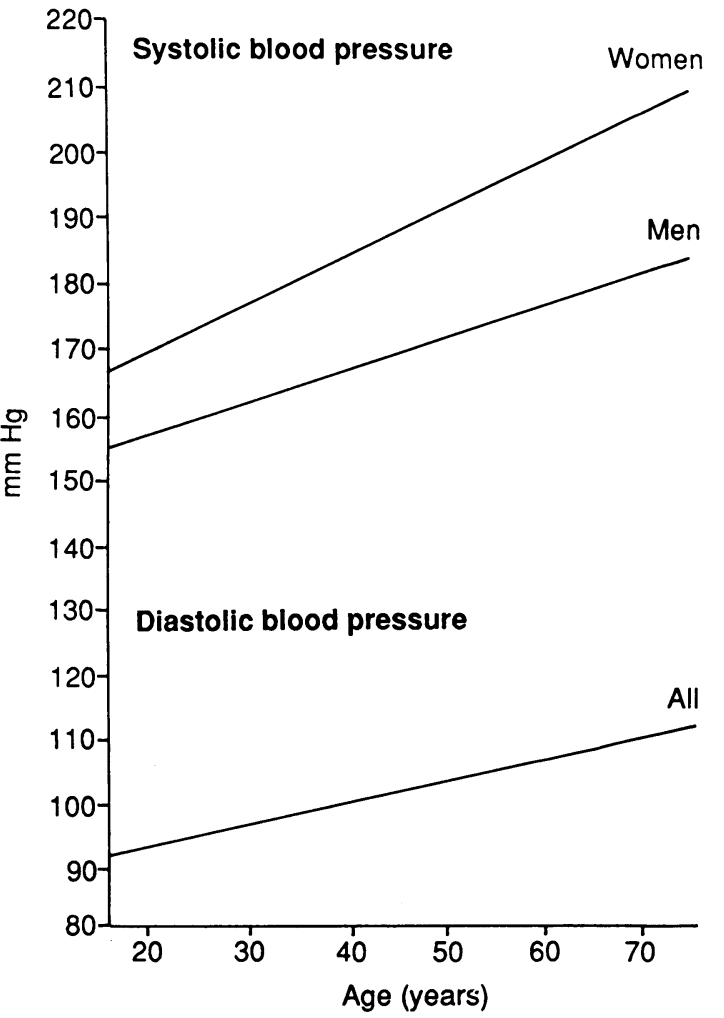

Norwegian blood pressure criteria for diagnosis of hypertension, indicating systolic and diastolic blood pressure screening thresholds

TABLE I - Number (percentage of age group) of subjects needing blood pressure monitoring before and after screening for hypertension

\begin{tabular}{lrrrrr}
\hline & \multicolumn{3}{c}{ Men } & & \multicolumn{2}{c}{ Women } \\
\cline { 2 - 3 } \cline { 5 - 6 } $\begin{array}{c}\text { Age } \\
\text { (years) }\end{array}$ & $\begin{array}{c}\text { Previously } \\
\text { monitored }\end{array}$ & $\begin{array}{c}\text { Newly } \\
\text { detected }\end{array}$ & & $\begin{array}{l}\text { Previously } \\
\text { monitored }\end{array}$ & $\begin{array}{c}\text { Newly } \\
\text { detected }\end{array}$ \\
\hline $20-$ & $125(2 \cdot 3)$ & $91(1 \cdot 6)$ & & $131(2 \cdot 4)$ & $30(0 \cdot 5)$ \\
$30-$ & $361(4 \cdot 5)$ & $154(1 \cdot 9)$ & & $246(3 \cdot 1)$ & $33(0 \cdot 4)$ \\
$40-$ & $363(6 \cdot 0)$ & $99(1 \cdot 6)$ & & $293(4 \cdot 8)$ & $54(0 \cdot 9)$ \\
$50-$ & $362(6 \cdot 5)$ & $113(2 \cdot 0)$ & & $379(6 \cdot 8)$ & $39(0 \cdot 7)$ \\
$60-$ & $362(5 \cdot 9)$ & $146(2 \cdot 4)$ & & $417(6 \cdot 6)$ & $47(0 \cdot 7)$ \\
$70-$ & $266(6 \cdot 6)$ & $107(2 \cdot 7)$ & & $326(6 \cdot 9)$ & $33(0 \cdot 7)$ \\
$80-$ & $74(5 \cdot 7)$ & $45(3 \cdot 5)$ & & $121(6 \cdot 9)$ & $15(0 \cdot 9)$ \\
$\geqslant 90$ & $5(4 \cdot 3)$ & $2(0 \cdot 9)$ & & $18(9 \cdot 7)$ & \\
\hline Total & $1918(5 \cdot 2)$ & $756(2 \cdot 1)$ & & $1931(5 \cdot 1)$ & $251(0 \cdot 7)$ \\
\end{tabular}

drugs. In addition, a fifth group consisted of those who did not attend for follow up examination.

\section{STATISTICS}

One way analysis of variance was used. The level of significance was defined as $p=0.05$.

\section{Results}

\section{BEFORE SCREENING}

All subjects participating in the screening were $\tilde{\omega}$ asked about their current blood pressure, and 64870 श $(86.5 \%)$ reported normal blood pressure not needing 0 treatment or monitoring. Of 3849 subjects whose blood pressure was being monitored nearly half (1918) were men, and there were significantly more men than women in the age group $30-49(724 v 539 ; \mathrm{p}<0.05)$ (table I). More women than men were receiving drug treatment for hypertension (3811 $v 2399)$ (table II).

\section{RESULTS OF SCREENING}

At screening 2399 subjects showed blood pressure readings above the thresholds given in the figure. After further examination they were divided into four groups by general practitioners.

Group 1: no treatment or monitoring needed $(n=547)-$ At screening the pulse rate in those who did not need 
further follow up was significantly raised compared with that in subjects with normal blood pressure (79.9 $v 74.9 ; \mathrm{p}<0.001$ ) (table III), indicating psychological tension. Their body mass index and the prevalence of self reported cerebral stroke were also significantly higher $(25.9 v 24.8$ and $2.7 \% v 1.2 \%$; both $\mathrm{p}<0.001)$ than in normal subjects, but prevalence of self reported myocardial infarction and of angina pectoris was not significantly different.

Group 2: needing blood pressure monitoring but not antihypertensive drugs $(n=1007)$ - In this group there were three times as many men as women (table III). Pulse rate and body mass index in this group were significantly higher than in normal subjects $(81.6 v$ 74.9 and $27 \cdot 1 v 24 \cdot 8$; both $p<0.001$ ), but the cardiovascular health of these patients was not significantly different.

Group 3: already being treated with antihypertensive drugs $(n=189)$-Before screening all these patients reported that they were not taking antihypertensive drugs, so that in the group was obtained different information from the patients and the doctors; this might suggest that the patients had dropped out from drug treatment. The pulse rate in this group was not higher than in normal subjects $(p=0.086)$, possibly indicating that they were used to having their blood pressure measured. This group had, however, a significantly higher prevalence of cardiovascular disease than all other groups (table III) indicating a higher risk of cardiovascular disease over several years.

Group 4: newly discovered hypertension needing drug treatment ( $n=406)$ - This group consisted of two thirds men (table III). Blood pressures at screening were considerably raised. Pulse rate was higher than in all other groups, possibly due to a high psychological tension at screening. Blood pressure remained raised when measured repeatedly by the general practitioner. Body mass index was significantly higher than in other groups, but cardiovascular disease was not more prevalent, which might indicate that the higher cardiovascular risk was of shorter duration than for patients already taking antihypertensive drugs.

Group 5: not attending for follow up $(n=250)$ - For 24 subjects in this group we obtained blood pressure readings when they were examined by a general practitioner: mean blood pressure was raised, comparable to that in patients for whom blood pressure monitoring was necessary (table III). This indicates that some of the patients who did not attend for examination after screening should have their blood pressure monitored.

\section{AFTER SCREENING}

After screening $406(6 \cdot 0 \%)$ newly diagnosed patients were defined by the general practitioners as needing antihypertensive drugs (table IV). Thus of all 6805 patients taking antihypertensive drugs after screening
TABLE IV-Previously and newly detected hypertensive patients needing drug treatment or blood pressure monitoring

\begin{tabular}{|c|c|c|c|}
\hline & $\begin{array}{l}\text { No }(\%) \text { needing } \\
\text { drug treatment }\end{array}$ & $\begin{array}{c}\text { No }(\%) \text { needing } \\
\text { blood pressure } \\
\text { monitoring }\end{array}$ & Total \\
\hline $\begin{array}{l}\text { Detected by screening } \\
\text { Previously detected }\end{array}$ & $\begin{array}{c}406(6 \cdot 0) \\
6399(94 \cdot 0)^{\star}\end{array}$ & $\begin{array}{l}1007(20 \cdot 7) \\
3849(79 \cdot 3)\end{array}$ & $\begin{array}{r}1413(12 \cdot 1) \\
10248(87 \cdot 9)\end{array}$ \\
\hline Total & $6805(100)$ & $4856(100)$ & $11661(100)$ \\
\hline
\end{tabular}

^Included 189 patients previously detected but not taking the drugs prescribed.

$94.0 \%$ had been identified before screening. Altogether 11661 (15.6\% of all participants) needed blood pressure surveillance after the screening and follow up examination, of whom $87.9 \%$ had been identified before screening.

\section{Discussion}

One of the problems of a programme for hypertension is to find the patients in need of health care. This study aimed at measuring the magnitude of this problem in a rural area where hypertension treatment was integrated in general practice.

\section{DEFINITION OF HYPERTENSION}

A crucial point is how to define hypertension. The most common thresholds are those set by the World Health Organisation $(160 / 95 \mathrm{~mm} \mathrm{Hg})^{10}$ and those recommended in the United States $(140 / 90 \mathrm{~mm} \mathrm{Hg}) .{ }^{26}$ These are the result of correlating the increased morbidity and mortality risks with results from large controlled clinical trials. Such studies pay much attention to side effects of drugs, but other treatment costs have been less emphasised until recently. ${ }^{27}$

The Norwegian thresholds were also developed through a sort of consensus. ${ }^{20}$ The aim was to find thresholds at which the benefit of treatment equalled the total costs of treatment (biological, social, and economic). The thresholds shown in the figure are considerably higher than those recommended by the World Health Organisation ${ }^{28}$ and those used in the United States; they have been widely accepted in Norway, ${ }^{29}$ being used in several epidemiological studies and also in a national programme for treating hypertension..$^{30}$

In many epidemiological studies hypertension is defined only by blood pressure and use of antihypertensive drugs. Our study, however, evaluated the diagnostic procedure in general practice, and hypertension was diagnosed after an overall clinica judgment. ${ }^{20212627}$

\section{STUDY DESIGN}

It is important to consider whether the study design might have influenced the results. During the years before the screening there were some intervention

TABLE III - Results of screening and follow up for subjects with normal blood pressure and those classified into subgroups after follow up examination by general practitioners

\begin{tabular}{|c|c|c|c|c|c|c|}
\hline & $\begin{array}{c}\text { Normal blood } \\
\text { pressure } \\
\text { before screening } \\
(n=64870)\end{array}$ & $\begin{array}{c}\text { Drugs and } \\
\text { monitoring not } \\
\text { needed } \\
(\mathrm{n}=547)\end{array}$ & $\begin{array}{c}\text { Blood pressure } \\
\text { monitoring needed } \\
(\mathbf{n}=1007)\end{array}$ & $\begin{array}{c}\text { Previously taking } \\
\text { antihypertensive drugs } \\
(n=189)\end{array}$ & $\begin{array}{l}\text { Antihypertensive drugs } \\
\text { needed } \\
(n=406)\end{array}$ & $\begin{array}{l}\text { Did not attend } \\
\text { examination after } \\
\text { screening } \\
(\mathbf{n}=250)\end{array}$ \\
\hline Mean (range) age (years) & $47 \cdot 8(20 \cdot 101)$ & $51.9(21-98)$ & $52 \cdot 2(21-90)$ & $61 \cdot 8(22-87)$ & $58 \cdot 1(23-89)$ & $52 \cdot 5(21-84)$ \\
\hline No $(\%)$ women & $32462(50 \cdot 0)$ & $122(22 \cdot 3)$ & $251(24.9)$ & $61(32 \cdot 3)$ & $137(33 \cdot 8)$ & $59(23 \cdot 6)$ \\
\hline \multicolumn{7}{|l|}{$\begin{array}{l}\text { Mean (SD) blood pressure at screening } \\
(\mathrm{mm} \mathrm{Hg}) \text { : }\end{array}$} \\
\hline Systolic & $133 \cdot 9(21 \cdot 6)$ & $171 \cdot 1(29 \cdot 6)$ & $174 \cdot 7(25 \cdot 9)$ & $188 \cdot 8(27 \cdot 6)$ & $193.7(30 \cdot 0)$ & $177 \cdot 8(26 \cdot 7)$ \\
\hline Diastolic & $82 \cdot 6(11 \cdot 2)$ & $100 \cdot 8(9 \cdot 9)$ & $103 \cdot 3(11 \cdot 1)$ & $108 \cdot 5(11 \cdot 3)$ & $112 \cdot 4(12 \cdot 2)$ & $104 \cdot 0(12 \cdot 1)$ \\
\hline \multicolumn{7}{|l|}{$\begin{array}{l}\text { Mean (SD) blood pressure at examination } \\
(\mathrm{mm} \mathrm{Hg}) \text { : }\end{array}$} \\
\hline Systolic & & $152 \cdot 5(24 \cdot 8)(\mathrm{n}=503)$ & $163.0(22 \cdot 7)(n=992)$ & $171 \cdot 1(29 \cdot 8)(n=179)$ & $187 \cdot 0(28 \cdot 1)(n=403)$ & $169 \cdot 1(26 \cdot 5)(n=24)$ \\
\hline Diastolic & & $86.6(8.9)(n=503)$ & $94 \cdot 5(8 \cdot 6)(\mathrm{n}=994)$ & $97 \cdot 4(11 \cdot 5)(\mathrm{n}=179)$ & $107 \cdot 8(12 \cdot 2)(n=403)$ & $99 \cdot 9(15 \cdot 2)(n=24)$ \\
\hline Mean (SD) pulse at screening (beats/min) & $74 \cdot 9(12 \cdot 4)$ & $79 \cdot 9(15 \cdot 0)$ & $81 \cdot 6(14 \cdot 8)$ & $76 \cdot 5(14.9)$ & $85 \cdot 1(16 \cdot 5)$ & $83 \cdot 5(16 \cdot 6)$ \\
\hline Mean (SD) body mass index & $24 \cdot 8(3 \cdot 7)$ & $25 \cdot 9(4 \cdot 0)$ & $27 \cdot 1(4 \cdot 6)$ & $27 \cdot 4(4 \cdot 2)$ & $28 \cdot 4(5 \cdot 4)$ & $26 \cdot 9(4 \cdot 3)$ \\
\hline No $(\%)$ reporting cerebral stroke & $760(1 \cdot 2)$ & $15(2 \cdot 7)$ & $15(1.5)$ & $16(8 \cdot 5)$ & $6(1 \cdot 5)$ & $3(1 \cdot 2)$ \\
\hline No $(\%)$ reporting myocardial infarction & $1247(1.9)$ & $10(1.8)$ & $21(2 \cdot 1)$ & $8(4 \cdot 2)$ & $2(0.5)$ & $3(1 \cdot 2)$ \\
\hline No $(\%)$ reporting angina pectoris & $2040(3 \cdot 2)$ & $15(2 \cdot 7)$ & $31(3 \cdot 1)$ & $23(12 \cdot 2)$ & $9(2 \cdot 2)$ & $10(4 \cdot 0)$ \\
\hline
\end{tabular}
of age group) of subjects treated \begin{tabular}{rrr}
$80-$ & $320(18 \cdot 3)$ & $4(0 \cdot 2)$ \\
\hline
\end{tabular} Total $3811(10 \cdot 0) \quad 138(0 \cdot 4)$ 
activities in the county. Doctors continually receive information from drug companies covering hypertension detection and treatment. The activities initiated by our study group were not extensive compared to this everyday information. ${ }^{29}$ As well, most patients already taking antihypertensive drugs reported that their hypertension had been diagnosed several years before the screening, and we found no evidence of increased diagnostic activities in the period immediately before the start of the screening. Therefore we do not believe that the intervention activities immediately before the screening could explain the good results.

The study was not designed to evaluate overtreatment, but we think that some of the elderly patients might not require drug treatment. This would, however, not have any dramatic impact on the proportion of patients with hypertension detected previously.

Some people would be expected to become hypertensive during the screening period. In other studies annual incidence has varied from $1 \cdot 5 \%$ to $19 \cdot 2 \%,{ }^{31-33}$ depending on the blood pressure thresholds applied. An incidence of $0.5 \%$ a year would give 750 newly identified patients within the county during the two year screening period. Some of these people might have had their hypertension detected by general practitioners even if the screening had not taken place.

\section{SCREENING OR CASE FINDING AS STRATEGY?}

Regular mass screening procedures are supposed to be the most efficient way to diagnose hypertension. Several arguments are, however, raised against routine screening.

Some people needing follow up and treatment do not attend for screening, and some drop out of the follow up procedures. In this study the participation rate was very high $(88 \cdot 1 \%)$, especially in the middle age groups, as expected. Follow up of a $10 \%$ sample of those not attending for screening showed that a minority of the elderly non-participants were very ill, but no difference in prevalence of hypertension was found between non-attenders and other groups. Some of the $250(10 \cdot 4 \%)$ patients who screened positive but did not attend for the follow up examination probably needed blood pressure treatment and monitoring. Such selection bias and non-participation problems occur in all screening procedures.

In all screening surveys for blood pressure there are some false positives - that is, people who screen positive but have normal blood pressure at follow up. We must assume that these people were concerned about their blood pressure. Cost-benefit considerations of screening as a routine strategy should also include psychological, social, and economic consequences for these people.

The economic cost of screening procedures is another argument against the screening strategy. The case finding method is part of general practitioners' daily practice, and the doctor is supposed to measure blood pressure in patients who visit for any reason. In Norway, where $90 \%$ of the population visits their general practitioner in a five year period, this is a convenient method. The strategy demands little extra expenditure and probably has no psychological or social side effects. The general practitioners in NordTrøndelag county were advised to use the case finding method for some years before the screening, and the good screening result indicates that this strategy was effective.

The Nord-Trøndelag health survey 1984-6 was performed by the national health screening service, and we thank $\mathrm{K}$ Bjartveit, P G Lund-Larsen, and E Risan for invaluable support. The study was financially supported by the National Association for Public Health, the Norwegian Research
Council for Science and the Humanities, the County Council of Nord-Trøndelag, and the Department for Health and Social Affairs. We are also deeply indebted to E Fiærtoft and the other members of the steering committee for encouragement, to the general practitioners in Nord-Trøndelag for supplying data, to Aina Enes and Inger Duvsete Holbø for technical assistance and patience in preparing the data and the text, and, most of all, to the people of Nord-Trøndelag who with their support made this study possible.

1 Wilber JA, Barrow JG. Hypertension: a community problem. Am $\mathcal{f}$ Med 1972;52:653-63.

2 Stamler J, Stamler R, Riedlinger WR, Algera G, Roberts RH. Hypertension screening of 1 million Americans: community hypertension evaluation clinic (CHEC) program, 1973 through 1975. JAMA 1976;235:2299-306.

3 Labarthe DR, Krishan I, Nobrega FT, et al. The Mayo three-community hypertension control program. I: Design and initial screening results. Mayo Clin Proc 1979;54:289-98.

4 Tuomilehto J, Puska P, Virtamo J, Nissinen A. Hypertension control in North Karelia before the intervention of the North Karelia project. Scand $\mathcal{J}$ So Med 1980;8:9-15.

5 Sigurdsson JA, Bengtsson C. Prevalence and management of arterial hypertension in a population sample of Swedish women. Scand 7 Soc Med 1981;9:41-7.

6 Berglund G, Isacsson SO, Rydén L. Vårdprogram for högt blodtryck. Skaraborgs läns landsting. Stockholm: Swedish Planning and Rationalization Institute, 1977. (Rapport S 52.)

7 Moser M, Guyther JR, Finnerty F, et al. Report of the joint national committee on detection, evaluation, and treatment of high blood pressure. A cooperative study. IAMA 1977;237:255-61.

8 Aromaa $\mathrm{A}$, Pyörala $\mathrm{K}$. Finlänsk vårdprogram for arteriell hypertension. Nord Med 1979;92:204-8.

9 Royal College of General Practitioners. Prevention of arterial disease in general practice. London: RCGP, 1981.

10 Gross F, Pisa Z, Strasser T, Zanchetti A. Management of arterial hyperten-

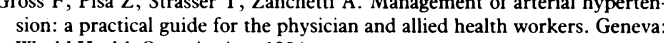
sion: a practical guide for the physicai
World Health Organisation, 1984.

11 Hart JT. Hypertension. London: Churchill Livingstone 1980.

11 Hart JT. Hypertension. London: Churchill Livingstone 1980. changes in blood pressure level in patients included in the hypertension changes in blood pressure level in patients included in the hypertenti
register of the North Karelia Project. Scand F Soc Med 1980;8:17-23.

13 Krishan I, Davis CS, Nobrega FT, Smoldt RK. The Mayo three-community hypertension control program. IV: Five-year outcomes of intervention in entire communities. Mayo Clin Proc 1981;56:3-10.

14 Råstam L, Berglund G, Isacsson SO, Rydén L. The Skaraborg hypertension project. II: Feasibility of a medical care program for hypertension. Acta Med Scand 1986;219:249-60.

15 Berglund G, Isacsson SO, Rydén L. Modell for omhändertagande av patienter med högt blodtryck. Läkartidningen 1978;75:4253-6.

16 Hines E, Powell CE, Metts JC, Grimes V, Satcher D. Regional and local high blood pressure control programs. F Med Assoc Ga 1981;70:353-5.

17 Subcommittee on Definition and Prevalence of the 1984 Joint National Committee. Hypertension prevalence and the status of awareness, treatment, and control in the United States: final report. Hypertension 1985;7:457-68. Smith WCS, Lee AJ, Crombie IK, Tunstall-Pedoe H. Cont
pressure in Scotland: the rule of halves. $B M$ I 1990;300:981-3.

19 Kvamme J-I. Hypertensjon $i$ distriktshelsetjenesten. Reformer $i$ distriktshelsetjenesten III. Tromsø: Institutt for Samfunnsmedisin Skriftserie, 1980.

20 Waaler HT, Helgeland A, Hjort PF, et al. Hoyt blodtrykk: behandlingsprogram, utbytte, kostnader. Oslo: Gruppe for Helsetjenesteforskning, Norges Allmennvitenskaplige Forskningsråd, 1978. (Rapport 5.)

21 Holmen J, Dehli O, Fiærtoft E, et al. Blodtrykksprogram for Nord-Trondelag. Oslo: Gruppe for Helsetjenesteforskning Norges Allmennvitenskaplige Forskningsråd, 1981.

22 Eilertsen E, Humerfelt $S$. The blood pressure in a representative population sample. Acta Med Scand 1968;183:293-305.

23 Holmen J. "Trimmen, trokket og tablettan": en analyse av blodtrykksbehandlingen $i$ Nord-Trondelag 1980-81. Oslo: Gruppe for Helsetjenesteforskning, Statens Institutt for Folkehelse, 1983. (Rapport 10.)

24 Holmen J, Forsén L, Skjerve K, Gorseth M, Midthjell K, Oseland A. “Moter moter ikke?". Helseundersøkelsen i Nord-Trondelag 1984-86: sammenliknende analyse av de som motte og de som ikke motte. Verdal: Avdeling for Helsetjenesteforskning, Statens Institutt for Folkehelse, 1989. (Rapport 5 .)

25 Holmen J, Midthjell K, Bjartveit K, et al. The Nord-Trondelag health survey 1984-86. Purpose, background and methods. Participation, non-participation 1984-86. Purpose, background and methods. Participation, non-participation
and frequency distributions. Verdal: Unit for Health Services Research, and frequency distributions. Verdal: Unit for Health
National Institute of Public Health, 1990. (Report 4.)

26 Joint National Committee. The 1988 Report of the joint national committee on detection, evaluation, and treatment of high blood pressure. Arch Intern Med 1988; 148:1023-38.

27 British Hypertension Society Working Party. Treating mild hypertension. BMF 1989;298:694-8

28 WHO/ISH Fifth Mild Hypertension Conference: 1989 guidelines for the management of mild hypertension: memorandum from a WHO/ISH meeting. I Hypertens 1989;7:689-93.

29 Holmen J. Kliniske handlingsprogrammer-tvangstroye eller stotte? Analyse av primarleges bruk av og holdninger til et handlingsprogram for hogt blodtrykk. Verdal: Avdeling for Helsetienesteforskning. Statens Institutt for Folkehelse, 1989. (Rapport 1.)

30 Holmen J, Forsdahl A, Kvamme JI, et al. Hoyt blodtrykk. NSAM's handlingsprogram for almenpraksis. Oslo: Gruppe for Helsetjenesteeffektivisering, 1986. (Rapport 11.)

31 Berglund G, Wilhelmsen L, Werkö L. Blood pressure development and characteristics of subjects with moderate blood pressure elevation. Acta Med Scand 1974;196:301-6.

32 Dannenberg AL, Garrison RJ, Kannel WB. Incidence of hypertension in the Framingham study. Am $\mathcal{F}$ Public Health 1988;78:676-9.

33 Stamler R, Stamler J, Gosch FC, et al. Primary prevention of hypertension by nutritional-hygienic means. FAMA 1989;262:1801-7.

(Accepted 13 November 1990$)$ 